\title{
Penerapan Metode Pembelajaran Small Group Discussion untuk Meningkatkan Hasil Belajar dan Keaktifan Mahasiswa
}

Wiwin Putriawati

Program Studi Pendidikan Matematika, STKIP Paracendekia NW Sumbawa, Jl. Lintas Sumbawa-Bima Km 5, Sumbawa Besar, Indonesia 84316

Email Korespondensi:putriawatiw29@gmail.com

\begin{tabular}{|c|c|}
\hline Article Info & Abstract \\
\hline $\begin{array}{l}\text { Article History } \\
\text { Received: March } 2019 \\
\text { Revised: May } 2019 \\
\text { Published: June } 2019\end{array}$ & \multirow{2}{*}{$\begin{array}{l}\text { The Implementation of Small Group Discussion Learning Methods to Improve } \\
\text { Learning Outcomes and Student Activity. This study aims to improve the learning } \\
\text { outcomes and activeness of STKIP Paracendekia NW English Language } \\
\text { Education students in the Basic Natural Sciences (IAD) course through the } \\
\text { application of small group discussion methods. Student cognitive learning } \\
\text { outcomes are still low, so it is necessary to apply new methods in learning. The } \\
\text { activity in this research includes activeness in asking questions, answering } \\
\text { questions, discussing, and presenting. This research is a classroom action } \\
\text { research with two cycles. Stages of research include planning, implementation, } \\
\text { observation, and reflection. The subjects of this study were } 55 \text { students of STKIP } \\
\text { Paracendekia NW Sumbawa English Language Education semester I (one) in the } \\
\text { Basic Science (IAD) course. Data collection techniques are tests (pretest and post } \\
\text { test) and non-tests (observation). The result of this study were an increase in } \\
\text { student learning outcomes and activity. Learning outcomes can be seen from the } \\
\text { value of the pretest and post test. The average value of pretest and post test in cycle } \\
\text { I is } 65,22 \text { and } 70,67 \text {. Cycle II, the average value of the post test is } 85,34 \text {. Student } \\
\text { activeness before the action in only } 15 \text { active students. After being given the action, } \\
\text { in the first cycle, students were activein asking, answering questions, discussing, } \\
\text { and presenting } 30 \text { peoples. In cycle II, active students reached } 42 \text { peoples. }\end{array}$} \\
\hline $\begin{array}{l}\text { Keywords } \\
\text { Small Group Discussion; } \\
\text { Learning Outcomes; } \\
\text { Student Activity }\end{array}$ & \\
\hline Informasi Artikel & ADSt \\
\hline $\begin{array}{l}\text { Sejarah Artikel } \\
\text { Diterima: Maret } 2019 \\
\text { Direvisi: Mei } 2019 \\
\text { Dipublikasi: Juni } 2019\end{array}$ & \multirow{2}{*}{$\begin{array}{l}\text { Penelitian ini bertujuan untuk meningkatkan hasil belajar dan keaktifan mahasiswa } \\
\text { Pendidikan Bahasa Inggris STKIP Paracendekia NW Sumbawa pada mata kuliah } \\
\text { Ilmu Alamiah Dasar (IAD) melalui penerapan metode pembelajaran small group } \\
\text { discussion. Keaktifan dalam penelitian ini meliputi keaktifan dalam bertanya, } \\
\text { menjawab pertanyaan, berdiskusi, dan presentasi. Penelitian ini merupakan } \\
\text { penelitian tindakan kelas dengan dua siklus. Tahapan penelitian meliputi } \\
\text { perencanaan, pelaksanaan, observasi, dan refleksi. Subjek dari penelitian ini } \\
\text { berjumlah } 55 \text { orang mahasiswa Pendidikan Bahasa Inggris STKIP Paracendekia } \\
\text { NW Sumbawa semester I (satu) pada mata kuliah Ilmu Alamiah Dasar (IAD). Data } \\
\text { penelitian didapatkan melalui pemberian tes dan observasi menggunakan } \\
\text { instrument tes dan lembar observasi. Hasil penelitian menunjukkan adanya } \\
\text { peningkatan hasil belajar dan keaktifan mahasiswa dengan nilai rata-rata pretest } \\
\text { dan posttest pada siklus I yaitu } 65,22 \text { dan } 70,67 \text { dan pada siklus II, nilai rata-rata } \\
\text { posttest yaitu } 85,34 \text {. Keaktifan mahasiswa pada siklus I ( } 30 \text { orang) dan siklus II } \\
\text { (42 orang) juga dinyatakan meningkat yang ditunjukkan dengan mahasiswa aktif } \\
\text { bertanya, menjawab pertanyaan, berdiskusi, dan presentasi. }\end{array}$} \\
\hline $\begin{array}{l}\text { Kata kunci } \\
\text { Small Group Discussion; } \\
\text { Hasil Belajar; } \\
\text { Keaktifan Mahasiswa }\end{array}$ & \\
\hline & \\
\hline
\end{tabular}




\section{PENDAHULUAN}

Pendidikan merupakan hal yang sangat penting bagi suatu generasi. Generasi akan semakin maju dan terpelajar dengan adanya pendidikan yang layak. Pendidikan di perguruan tinggi merupakan pendidikan tingkat orang dewasa, artinya bukan lagi seperti pendidikan waktu di SMA. Mahasiswa pada jenjang perguruan tinggi dituntut lebih aktif dalam perkuliahan. Pembelajaran aktif bertolak dari pandangan bahwa dalam pembelajaran mahasiswalah yang harus aktif, dalam arti mahasiswa harus aktif mengkonstruksikan pengetahuan di dalam dirinya sendiri. Pengetahuan merupakan ciptaan manusia yang dikonstruksikan dari pengalaman dan interaksinya dengan lingkungan. Proses pembentukannya berjalan terus-menerus dan setiap kali terjadi rekonstruksi. Hal ini terjadi karena adanya pemahaman baru. Pembelajaran aktif bertujuan untuk mengoptimalkan penggunaan semua potensi yang dimiliki oleh mahasiswa, sehingga dapat mencapai hasil belajar yang memuaskan (Eveline dalam Purwanti, 2017).

Mata kuliah Ilmu Alamiah Dasar (IAD) adalah salah satu kelompok Mata Kuliah Dasar Umum (MKDU) yang diberikan pada semua Fakultas Non-eksakta di Perguruan Tinggi seluruh Indonesia dengan beban studi 2 sks (Ali \& Rahma, 2015). Jadi, mata kuliah IAD merupakan salah satu mata kuliah yang wajib ditempuh oleh mahasiswa Pendidikan Bahasa Inggris Sekolah Tinggi Keguruan dan Ilmu Pendidikan (STKIP) Paracendekia NW Sumbawa semester I (satu). IAD merupakan kumpulan pengetahuan tentang konsep-konsep dasar dalam bidang Ilmu Pengetahuan Alam (IPA) dan Teknologi yang harus dikuasai oleh mahasiswa sebagai syarat untuk lulus mata kuliah IAD. Menguasai konsep IPA/sains bukan berarti mahasiswa dapat menghafal semua konsep, namun mahasiswa juga harus dapat memahami, memecahkan persoalan IPA/sains dan menerapkan dalam kehidupan sehari-hari. Salah satu cara untuk melihat penguasaan konsep IPA/sains yang baik adalah dengan melihat hasil belajar mahasiswa, terutama hasil belajar kognitif. Hasil belajar kognitif mahasiswa Pendidikan Bahasa Inggris semester I terhadap mata kuliah IAD masih rendah. Hal itu dapat dilihat dari perolehan nilai Ujian Tengah Semester (UTS) 55 mahasiswa, dengan jumlah mahasiswa yang memiliki nilai masih di bawah kriteria ketuntasan minimal (75) yaitu 26 orang. Melihat hasil nilai UTS yang belum baik, maka dosen perlu mengubah metode perkuliahan agar hasil belajar mahasiswa meningkat.

Dosen menggunakan metode ceramah dengan teknik presentasi pada awal perkuliahan, dengan tujuan agar mahasiswa menjadi aktif. Setelah perkuliahan berjalan, ternyata hanya 15 mahasiswa yang aktif dalam bertanya dan menjawab pertanyaan, sehingga lebih banyak mahasiswa yang pasif yang hanya mendengarkan tanpa adanya interaksi apapun yang diberikan di dalam kelas. Hal ini membuat dosen perlu untuk memikirkan solusi atas permasalahan ini di kelas, yaitu dengan mengganti metode dalam perkuliahan. Metode yang dipilih dosen untuk mengaktifkan mahasiswa yaitu dengan menerapkan metode pembelajaran small group discussion atau diskusi pada kelompok kecil. Small group discussion merupakan proses pembelajaran dengan diskusi pada kelompok kecil dengan tujuan agar mahasiswa dapat memecahkan persoalan-persoalan yang dihadapi dan agar keaktifan mahasiswa meningkat. Berdasarkan penelitian yang telah dilakukan oleh Nafsri (2014) dan Purwanti (2017) menunjukkan bahwa small group discussion dapat meningkatkan hasil belajar IPA siswa dan mahasiswa. Berdasarkan data hasil penelitian yang telah dilakukan oleh Nafsri (2014) mengungkapkan ketuntasan belajar siswa dari $61,50 \%$ pada siklus I menjadi $88,46 \%$ pada siklus II mengakibatkan terjadinya peningkatan ketuntasan belajar siswa sebesar $26,96 \%$, dan berdasarkan hasil penelitian Purwanti (2017) menyatakan bahwa nilai rata-rata mahasiswa pada siklus I adalah 68,09 meningkat menjadi 81,58 pada siklus II. Jadi, terjadi peningkatan yang signifikan terhadap ketuntasan belajar siswa maupun nilai rata-rata mahasiswa. Selain itu, Purwanti (2017) juga melihat peningkatan jumlah mahasiswa yang aktif dari sebelum adanya perlakuan/tindakan dengan setelah adanya perlakuan/tindakan. Keaktifan mahasiswa sebelum 
adanya tindakan yaitu hanya 12 mahasiswa yang aktif. Siklus I, mahasiswa yang aktif dalam bertanya, menjawab pertanyaan, berdiskusi dan presentasi ada 28 orang, dan pada siklus II mahasiswa yang aktif mencapai 39 orang. Peran dosen dalam pemilihan metode pembelajaran akan sangat berpengaruh pada proses perkuliahan. Penggunaan metode yang tidak sesuai dengan tujuan pengajaran akan menjadi kendala dalam mencapai tujuan yang dirumuskan (Djamarah dkk, 2013). Oleh karena itu, efektivitas penggunaan metode dapat terjadi bila ada kesesuaian metode dengan semua komponen perkuliahan yang telah direncanakan.

Melihat hasil penelitian terdahulu yang telah dilakukan oleh Nafsri (2014) dan Purwanti (2017), dosen ingin melakukan penelitian dengan penerapan metode pembelajaran small group discussion untuk meningkatkan hasil belajar kognitif dan keaktifan mahasiswa Pendidikan Bahasa Inggris semester I STKIP Paracendekia NW Sumbawa. Metode diskusi merupakan cara penyajian pembelajaran, di mana mahasiswa dihadapkan pada suatu masalah yang dapat berupa pernyataan ataupun pertanyaan yang bersifat problematis untuk dibahas dan dipecahkan bersama (Djamarah dkk, 2013).

\section{METODE}

Penelitian ini merupakan Penelitian Tindakan Kelas (PTK). Penelitian Tindakan Kelas merupakan salah satu upaya yang dapat dilakukan oleh dosen untuk meningkatkan kualitas peran dan tanggung jawab tenaga pendidik/tenaga pengajar khususnya dalam pengelolaan pembelajaran (Sanjaya, 2010; dalam Purwanti, 2017). Prosedur dalam penelitian ini mengacu pada langkah-langkah PTK yang dikemukakan oleh Kurt Lewin. Kurt Lewin menjelaskan bahwa ada 4 (empat) hal yang harus dilakukan dalam proses penelitian tindakan yakni: perencanaan, tindakan, observasi, dan refleksi. Pelaksanaan penelitian tindakan kelas adalah proses yang terjadi dalam suatu lingkaran yang terus menerus (Sanjaya, 2010; dalam Purwanti, 2017). PTK yang dilakukan dosen berangkat dari permasalahan yang ada di kelas yaitu hasil belajar dan keaktifan mahasiswa yang rendah. Penelitian ini melibatkan dua mahasiswa semester tujuh yang baru selesai PPL/KKN untuk membantu dosen dalam mengobservasi mahasiswa. Penelitian ini dirancang dalam dua siklus. Siklus pertama dimulai dari tahap perencanaan, pelaksanaan, observasi, dan refleksi. Tahap perencanaan dimulai dari menyiapkan Satuan Acara Perkuliahan (SAP) mata kuliah IAD. Dosen juga menyiapkan lembar observasi untuk mahasiswa. Tahap selanjutnya yaitu pelaksanaan. Dosen melaksanakan penelitian sesuai dengan SAP yang telah dibuat yaitu menggunakan metode pembelajaran small group discussion dan dibantu oleh mahasiswa semester tujuh untuk mengobservasi mahasiswa dan selanjutnya tahap terakhir yaitu tahap refleksi. Refleksi dilakukan untuk melihat secara keseluruhan pada proses perkuliahan melalui penerapan metode pembelajaran small group discussion. Hasil refleksi inilah yang digunakan untuk melangkah ke siklus selanjutnya. Siklus kedua merupakan hasil refleksi dari siklus pertama.

\section{Instrumen Penelitian}

Instrumen penelitian adalah alat atau fasilitas yang digunakan oleh peneliti dalam mengumpulkan data agar pekerjaan lebih mudah dan hasilnya baik, dalam arti lebih cermat, lengkap, dan sistematis sehingga lebih mudah diolah (Arikunto, 2009; dalam Putriawati, 2014). Penelitian ini menggunakan instrumen tes dan non tes (lembar observasi). Instrumen tes berupa soal-soal uraian untuk mendapatkan nilai mahasiswa pada akhir pembelajaran. Lembar observasi digunakan sebagai pedoman untuk melakukan pengamatan guna memperoleh data yang diinginkan. Lembar observasi yang digunakan dalam penelitian ini adalah lembar observasi keaktifan mahasiswa yang digunakan untuk mengamati keaktifan mahasiswa dalam hal bertanya, menjawab pertanyaan, berdiskusi, dan presentasi dan keterlaksanaan pembelajaran yang dilakukan oleh dosen dan mahasiswa di dalam kelas seperti disajikan pada Tabel 1 dan Tabel 2. 
Tabel 1. Instrumen Lembar Observasi Mahasiswa Selama Pembelajaran

\begin{tabular}{|c|c|c|c|c|c|c|c|c|}
\hline \multirow{3}{*}{ No. } & \multirow{3}{*}{ Aspek Penilaian } & \multicolumn{6}{|c|}{ Nama Mahasiswa } & \multirow{3}{*}{$\begin{array}{l}\text { Total jumlah mahasiswa } \\
\text { yang tampak pada setiap } \\
\text { aspek penilaian }\end{array}$} \\
\hline & & \multicolumn{2}{|c|}{$\mathrm{ABC}$} & \multicolumn{2}{|c|}{ GHI } & \multicolumn{2}{|c|}{ MNO } & \\
\hline & & $\mathrm{Ya}$ & Tidak & $\mathrm{Ya}$ & Tidak & $\mathrm{Ya}$ & Tidak & \\
\hline 1. & $\begin{array}{l}\text { Mengajukan pertanyaan saat } \\
\text { diskusi dan pembelajaran } \\
\text { berlangsung }\end{array}$ & & & & & & & \\
\hline 2. & $\begin{array}{l}\text { Menjawab pertanyaan yang } \\
\text { diajukan oleh mahasiswa lain } \\
\text { dan dosen }\end{array}$ & & & & & & & \\
\hline 3. & $\begin{array}{l}\text { Melakukan diskusi ketika } \\
\text { proses presentasi berlangsung }\end{array}$ & & & & & & & \\
\hline 4. & $\begin{array}{l}\text { Melakukan presentasi dengan } \\
\text { baik }\end{array}$ & & & & & & & \\
\hline
\end{tabular}

Tabel 2. Instrumen Lembar Observasi Dosen Selama Pembelajaran

\begin{tabular}{|c|c|c|c|}
\hline No. & Aspek Penilaian & $\begin{array}{ll}\text { Ya } & \text { Tidak }\end{array}$ & Komentar Observer \\
\hline 1 & Menjelaskan tujuan pembelajaran kepada mahasiswa & & \\
\hline 2 & Menguasai bahan perkuliahan & & \\
\hline 3 & $\begin{array}{l}\text { Menggunakan bahasa yang mudah dimengerti } \\
\text { mahasiswa }\end{array}$ & & \\
\hline 4 & $\begin{array}{l}\text { Menerapkan metode pembelajaran sesuai SAP yang } \\
\text { telah dibuat }\end{array}$ & & \\
\hline 5 & Menguasai kelas & & \\
\hline 6 & Memberikan motivasi belajar kepada mahasiswa & & \\
\hline 7 & Menciptakan keterlibatan semua mahasiswa & & \\
\hline
\end{tabular}

\section{Teknik Pengumpulan Data}

\section{Teknik Tes}

Arikunto (dalam Putriawati, 2014) menyatakan bahwa tes merupakan alat atau prosedur yang digunakan untuk mengetahui atau mengukur ketuntasan belajar mahasiswa setelah mengikuti pembelajaran dengan cara dan aturan-aturan yang sudah ditetapkan. Tes yang diberikan pada penelitian ini berupa soal-soal uraian pada materi mata kuliah Ilmu Alamiah Dasar (IAD).

Observasi (pengamatan)

Diperoleh melalui pengamatan langsung oleh peneliti dalam setiap pertemuan di kelas. Pada saat proses diskusi, dosen dibantu oleh dua mahasiswa semester tujuh melakukan observasi untuk melihat keaktifan mahasiswa dan keterlaksanaan pembelajaran.

\section{Teknik Analisis Data}

Data dari Para Ahli Melalui Expert Judgment

Instrumen sebelum digunakan dalam uji coba di kelas, maka dilakukan validasi terlebih dahulu oleh para ahli. Validasi instrumen meliputi validasi konstruk, isi dan kelugasan kalimat instrumen tes kemampuan kognitif mahasiswa terhadap mata kuliah IAD yang disajikan dalam bentuk soal uraian dan lembar observasi mahasiswa. Validasi ini dilakukan oleh dua dosen ahli yang mengacu pada kriteria penetapan kelayakan butir tes. Nilai kelayakan dari aspek konstruksi untuk setiap butir instrumen oleh para ahli dijumlah dan dihitung persentasenya sebagai berikut:

$P(\%)=\frac{\text { Jumlahskor hasil pengumpulandata }}{\text { Skor total kriteria }} \times 100 \%$

Skor total kriteria $=$ jumlah skor tertinggi aspek yang diukur. 
Persentase skor diinterpretasikan dengan menggunakan kategori persentase menurut Arikunto (dalam Putriawati, 2016) seperti disajikan pada Tabel 3 berikut.

Tabel 3. Kategori Persentase

\begin{tabular}{lll}
\hline Kategori & Skala & Persentase \\
\hline Sangat Valid & 4 & $76 \%-100 \%$ \\
Valid & 3 & $56 \%-75 \%$ \\
Cukup valid & 2 & $40 \%-55 \%$ \\
Kurang valid & 1 & Kurang dari 40\% \\
\hline
\end{tabular}

\section{Data Hasil Belajar}

Setelah memperoleh data hasil belajar, maka data tersebut merupakan data tentang ketuntasan belajar mahasiswa, kemudian dianalisis melalui pendekatan kualitatif dan kuantitatif.

\section{Ketuntasan Individu}

Setiap sekolah maupun perguruan tinggi memiliki standar ketuntasan yang berbeda-beda sesuai dengan tingkat kesukaran materi, kondisi dan kelengkapan sekolah yang bersangkutan. Sebagai dosen yang mengampu mata kuliah IAD di STKIP Paracendekia NW Sumbawa, dosen menetapkan bahwa setiap mahasiswa dalam proses belajar mengajar dinyatakan tuntas jika secara individu memperoleh nilai $\geq 75$, atau dengan kata lain dalam hal ini ketuntasan individu sama dengan Kriteria Ketuntasan Minimal (KKM).

\section{Ketuntasan Kelas}

Ketuntasan kelas dilakukan dengan menghitung rata-rata kelas pada masing-masing siklus.

Data Keaktifan Mahasiswa

Data ini dianalisis secara deskriptif setelah melihat hasil observasi yang telah dilaksanakan mahasiswa disesuaikan dengan lembar observasi yang telah dibuat, dengan kata lain menggunakan analisis kualitatif yang sifatnya subjektif. Hasil observasi yang dinyatakan dalam bentuk pernyataan-pernyataan sebagaimana adanya yang tampak dari perilaku yang diobservasi, diolah dengan melakukan analisis dan interpretasi seluruh hasil amatan. Hasil pengamatan dilihat dengan memberi tanda centang $(\sqrt{ })$ pada kolom "Ya" atau "Tidak" pada setiap aspek penilaian yang tampak. Peneliti berketetapan, bahwa kriteria keberhasilan keaktifan mahasiswa dengan menunjukkan setengah dari seluruh mahasiswa aktif dalam aspek penilaian. Jadi, dari 55 mahasiswa Pendidikan Bahasa Inggris setidaknya ada 27 atau 28 mahasiswa yang aktif.

\section{HASIL DAN PEMBAHASAN}

Data dari Para Ahli Melalui Expert Judgment

Hasil penelitian ini yang pertama adalah validitas konstruk instrumen tes kemampuan kognitif mahasiswa terhadap mata kuliah IAD yang telah divalidasi oleh dua dosen ahli. Hasil validasi konstruk disajikan pada Tabel 4.

Tabel 4. Hasil Validasi Instrumen Tes Kemampuan Kognitif Mahasiswa

\begin{tabular}{|c|c|c|c|c|}
\hline \multirow{2}{*}{ No. Soal } & \multicolumn{2}{|c|}{ Skor Validator } & \multirow{2}{*}{ Persen Skor $(\%)$} & \multirow{2}{*}{ Kriteria } \\
\hline & V1 & $\mathrm{V} 2$ & & \\
\hline 1 & 4 & 3 & 87,5 & Sangat Valid \\
\hline 2 & 3 & 3 & 75 & Valid \\
\hline 3 & 4 & 4 & 100 & Sangat Valid \\
\hline 4 & 4 & 2 & 75 & Valid \\
\hline 5 & 3 & 3 & 75 & Valid \\
\hline 6 & 4 & 3 & 87,5 & Sangat Valid \\
\hline 7 & 4 & 4 & 100 & Sangat Valid \\
\hline
\end{tabular}


Berdasarkan data dalam Tabel 4 dapat diberikan analisis sebagai berikut: (a) dilihat dari nilai persen skor, kedua validator memiliki kesepahaman yang tinggi dalam memberikan penilaian terhadap setiap butir soal. Dengan demikian, persen skor untuk masing-masing butir soal adalah sebuah kesatuan yang merepresentasi tingkat kevalidan (validitas) soal yang dibuat dari dimensi konstruk; (b) persen skor untuk masing-masing butir soal dinyatakan valid yang artinya dapat dipercaya sebagai pengukur indikator capaian pemahaman konsep dalam mata kuliah IAD.

Hasil validitas isi dan kelugasan kalimat dari kedua validator adalah tidak adanya konsepkonsep yang tidak benar dan menggunakan kalimat yang lugas dan tidak berbelit-belit. Hasil validasi instrumen lembar observasi mahasiswa dapat disajikan pada Tabel 5.

Tabel 5. Hasil Validasi Instrumen Lembar Observasi Mahasiswa

\begin{tabular}{|c|c|c|c|c|}
\hline \multirow{2}{*}{$\begin{array}{l}\text { No. Aspek } \\
\text { Penilaian }\end{array}$} & \multicolumn{2}{|c|}{ Skor Validator } & \multirow{2}{*}{ Persen Skor $(\%)$} & \multirow{2}{*}{ Kriteria } \\
\hline & V1 & $\mathrm{V} 2$ & & \\
\hline 1 & 4 & 4 & 100 & Sangat Valid \\
\hline 2 & 3 & 4 & 87,5 & Sangat Valid \\
\hline 3 & 3 & 3 & 75 & Valid \\
\hline 4 & 4 & 3 & 87,5 & Sangat Valid \\
\hline
\end{tabular}

Berdasar data dalam Tabel 5 dapat diberikan analisis, bahwa kedua validator memiliki kesepamahaman yang tinggi (di atas $75 \%$ ) dalam memberikan penilaian terhadap setiap butir soal sehingga merepresentasikan tingkat kevalidan (validitas) soal dari dimensi konstruk. Adapun hasil validasi isi dan kelugasan kalimat tidak adanya konsep yang tidak benar dan menggunakan bahasa yang lugas. Hasil validasi instrumen lembar observasi dosen dapat disajikan pada Tabel 6.

Tabel 6. Hasil Validasi Instrumen Lembar Observasi Dosen

\begin{tabular}{|c|c|c|c|c|}
\hline \multirow{2}{*}{$\begin{array}{l}\text { No. Aspek } \\
\text { Penilaian }\end{array}$} & \multicolumn{2}{|c|}{ Skor Validator } & \multirow{2}{*}{ Persen Skor $(\%)$} & \multirow{2}{*}{ Kriteria } \\
\hline & V1 & $\mathrm{V} 2$ & & \\
\hline 1 & 4 & 4 & 100 & Sangat Valid \\
\hline 2 & 4 & 3 & 87,5 & Sangat Valid \\
\hline 3 & 4 & 4 & 100 & Sangat Valid \\
\hline 4 & 3 & 4 & 87,5 & Sangat Valid \\
\hline 5 & 3 & 3 & 75 & Valid \\
\hline 6 & 3 & 3 & 75 & Valid \\
\hline 7 & 4 & 3 & 87,5 & Sangat Valid \\
\hline
\end{tabular}

Berdasar pada data pada Tabel 6 dapat diberikan analisis, bahwa kedua validator memiliki kesepamahaman yang tinggi (di atas 75\%) dalam memberikan penilaian terhadap setiap butir soal sehingga merepresentasikan tingkat kevalidan (validitas) soal dari dimensi konstruk. Adapun hasil validasi isi dan kelugasan kalimat tidak adanya konsep yang tidak benar dan menggunakan bahasa yang lugas.

\section{Data Hasil Belajar}

Nilai hasil belajar mahasiswa dilihat dari kenaikan rata-rata nilai posttest pada setiap siklus. Hasil rata-rata nilai pretest dan posttest dapat dilihat pada Tabel 7.

Tabel 7. Nilai Rata-rata Pretest dan Posttest Siklus I dan Siklus II Mahasiswa Pendidikan Bahasa Inggris STKIP Paracendekia NW Sumbawa

\begin{tabular}{lll}
\hline Test & Siklus I & Siklus II \\
\hline Pretest & 65,22 & - \\
Posttest & 70,67 & 85,34 \\
\hline
\end{tabular}

Tabel 7 menunjukkan hasil dari rata-rata pretest dan posttest siklus I dan II. Dari tabel dapat kita lihat bahwa adanya kenaikan nilai pretest dan posttest dari siklus I ke siklus II. 
Berdasarkan data pada tabel tersebut dapat dijelaskan bahwa pada hasil posttest siklus I belum mencapai nilai KKM yaitu 75, sehingga perlu adanya siklus lanjutan ke siklus II.

Aktivitas mahasiswa yang mencakup keaktifan mahasiswa dalam hal bertanya, menjawab pertanyaan, berdiskusi dan presentasi dapat dilihat pada Tabel 8 .

Tabel 8. Hasil Keaktifan Mahasiswa Pendidikan Bahasa Inggris STKIP Paracendekia NW

Sumbawa

\begin{tabular}{lll}
\hline Komponen yang dinilai & Siklus I & Siklus II \\
\hline Bertanya & 5 & 7 \\
Menjawab pertanyaan & 7 & 9 \\
Berdiskusi & 10 & 15 \\
Presentasi & 8 & 11 \\
Total & 30 & 42 \\
\hline
\end{tabular}

Berdasarkan data pada tabel ini, ditinjau dari kriteria keberhasilan yang telah dibuat oleh peneliti yaitu siswa yang aktif minimal berjumlah 27 atau 28 orang dari 55 mahasiswa Pendidikan Bahasa Inggris. Jadi, data yang tersaji dalam tabel baik pada siklus I maupun siklus II sudah menunjukkan kriteria keberhasilan dalam pembelajaran dengan menggunakan metode small group discussion.

Tahap selanjutnya yaitu refleksi. Dosen merefleksi perkuliahan yang telah berlangsung pada siklus I. Hasil refleksi berdasarkan komentar dan pengamatan observer yaitu perlu ditingkatkan adanya penguasaan kelas, lebih banyak memberikan motivasi, dan harus menciptakan keterlibatan kelas sehingga semua mahasiswa di dalam kelas menunjukkan keaktifannya. Setelah nilai pretest dan nilai posttest dianalisis dan diperoleh nilai rata-rata pretest yaitu 65,22 dan nilai rata-rata posttest 70,67. Hasil nilai pretest dan posttest pada siklus I dapat dilihat pada Tabel 5. Terlihat adanya kenaikan nilai rata-rata pretest ke posttest sebesar 5,45 . Adanya kenaikan nilai ini berarti terjadi peningkatan hasil belajar mahasiswa. Pada saat pretest hanya ada 12 mahasiswa yang nilainya tuntas atau di atas Ketuntasan Individu (KI) atau Kriteria Ketuntasan Minimal (KKM), dan setelah perkuliahan lalu mengerjakan posttest, ada 22 mahasiswa yang nilainya tuntas. KI atau KKM yaitu $\geq 75$. Berdasarkan hasil rata-rata pretest ke posttest ternyata nilai posttest masih di bawah nilai KKM, sehingga masih perlu adanya perbaikan pada siklus II. Hasil belajar yang masih rendah ini menunjukkan bahwa perkuliahan dengan small group discussion masih belum maksimal.

Pada perkuliahan sebelumnya, mahasiswa yang aktif ada 15 orang. Selama siklus I berjalan, keaktifan mahasiswa meningkat. Mahasiswa yang aktif dalam bertanya, menjawab pertanyaan, berdiskusi, dan presentasi ada 30 orang dengan rincian: sebanyak 5 orang yang bertanya, sebanyak 7 orang yang menjawab pertanyaan, sebanyak 10 orang yang berdiskusi, dan sebanyak 8 orang yang melakukan presentasi. Dengan diskusi pada kelompok kecil mereka menjadi lebih berani dalam bertanya maupun berpendapat dibandingkan sebelum diterapkannya diskusi pada kelompok kecil. Hal ini menunjukkan kriteria keberhasilan keaktifan mahasiswa pada siklus I sesuai dengan yang ditentukan peneliti.

\section{Data dari Para Ahli Melalui Expert Judgment}

Hasil validasi dari kedua dosen ahli menunjukkan adanya kesepahaman yang tinggi terhadap instrumen tes kemampuan kognitif dan instrumen lembar observasi yang telah dibuat oleh peneliti dengan persen skor di atas $75 \%$. Hal ini sesuai dengan apa yang dikatakan oleh Arikunto (dalam Putriawati, 2016) bahwa setiap butir instrumen yang memiliki persentase dengan kisaran $75 \%$ sampai dengan $100 \%$ dimaksud telah memenuhi persyaratan valid berdasarkan penilaian ahli sehingga layak untuk digunakan. Uraian hasil penelitian telah tersaji pada Tabel 4 yang dapat dijelaskan bahwa dari 7 (tujuh) soal instrumen tes pemahaman konsep yang telah dibuat oleh peneliti, terdapat 4 (empat) soal dengan kriteria sangat valid dan 3 (tiga) soal dengan kriteria valid. Jadi dapat disimpulkan bahwa instrumen tes yang telah dibuat telah 
mencapai syarat valid sesuai dengan apa yang dinyatakan oleh Arikunto (dalam Putriawati, 2016). Hasil validitas isi dan kelugasan kalimat menunjukkan bahwa tidak ada konsep yang tidak benar dan menggunakan kalimat/bahasa yang lugas.

Tabel 5 menyajikan data hasil validasi instrumen lembar observasi mahasiswa dengan 4 (empat) aspek penilaian yang dapat dirinci menjadi 3 (tiga) soal dengan kriteria validitas tinggi/ sangat valid dan 1 (satu) soal dengan kriteria valid. Hal ini menunjukkan adanya persyaratan kevalidan dengan kisaran persentase antara $75 \%$ sampai dengan $100 \%$, sehingga instrumen ini dapat digunakan sesuai dengan pernyataan Arikunto (2009).

Tabel 6 menyajikan data hasil validasi instrumen lembar observasi dosen selama pembelajaran dengan 7 (tujuh) aspek penilaian meliputi menjelaskan tujuan pembelajaran, menguasai bahan perkuliahan, menggunakan bahasa yang lugas, menerapkan metode pembelajaran, menguasai kelas, memberikan motivasi, dan menciptakan keterlibatan kelas. Dari ketujuh aspek penilaian ini, terdapat 5 (lima) aspek penilaian dengan kriteria sangat valid, dan 2 (dua) aspek lainnya berkriteria valid. Berdasarkan hasil persen skor yang tercantum pada Tabel 6 menunjukkan adanya persyaratan kevalidan dengan kisaran persentase antara 75\% sampai dengan $100 \%$, sehingga instrumen ini dapat digunakan sesuai dengan pernyataan Arikunto (dalam Putriawati, 2016). Hasil validitas isi dan kelugasan kalimat menunjukkan bahwa tidak ada konsep yang tidak benar dan menggunakan kalimat/bahasa yang lugas.

\section{Data Hasil Belajar}

Siklus I

Hasil pembelajaran sebelumnya masih rendah sehingga setelah diidentifikasi penyebabnya, dosen melakukan perbaikan perkuliahan dengan menerapkan metode pembelajaran lain yaitu small group discussion. Tujuan menerapkan metode ini adalah untuk meningkatkan hasil belajar kognitif dan keaktifan mahasiswa program studi Pendidikan Bahasa Inggris STKIP Paracendekia NW Sumbawa.

Data Tabel 7 menyajikan nilai pretest dan posttest pada siklus I dan siklus II. Berdasarkan data tersebut dapat dijelaskan bahwa pada siklus I nilai pretest mahasiswa masih berada jauh di bawah KKM dengan nilai 65,22. Hal ini menuntut peneliti untuk menerapkan metode pembelajaran small group discussion yang bertujuan meningkatkan hasil belajar mahasiswa. Setelah pembelajaran berakhir, mahasiswa melakukan posttest sehingga nilainya meningkat menjadi 70,67. Akan tetapi, nilai tersebut masih di bawah KKM sehingga masih perlu adanya siklus lanjutan yaitu ke siklus II.

Peningkatan nilai mahasiswa ini sesuai dengan hasil penelitian peneliti-peneliti sebelumnya (Nafsri, (2014); Purwanti, (2017)) yang mengungkapkan bahwa adanya peningkatan nilai mahasiswa menggunakan metode pembelajaran small group discussion. Hal ini sesuai dengan pernyataan Djamarah dkk, (2013) yang menyatakan bahwa penggunaan metode yang tidak sesuai dengan tujuan pengajaran akan menjadi kendala dalam mencapai tujuan yang dirumuskan. Oleh karena itu, efektivitas penggunaan metode dapat terjadi bila ada kesesuaian metode dengan semua komponen perkuliahan yang telah direncanakan. Metode diskusi merupakan cara penyajian pembelajaran, di mana mahasiswa dihadapkan pada suatu masalah yang dapat berupa pernyataan ataupun pertanyaan yang bersifat problematis untuk dibahas dan dipecahkan bersama (Djamarah dkk, 2013).

Segala kegiatan-kegiatan yang terjadi baik fisik maupun non-fisik merupakan sebuah aktivitas yang dapat dinilai (Anton, 2001). Aktivitas belajar mahasiswa adalah kegiatan yang dapat menunjang keberhasilan belajar karena seluruh aktivitas mahasiswa dalam proses belajar baik mulai kegiatan fisik sampai kegiatan psikis merupakan aktivitas belajar (Ardi, 2007). Jadi, dapat disimpulkan bahwa keaktifan mahasiswa merupakan segala kegiatan yang dilakukan dalam proses interaksi antara dosen dengan mahasiswa dalam rangka mencapai tujuan belajar 
dan aktivitas yang dilakukan akan ditekankan pada mahasiswa karena dengan adanya keaktifan dan aktivitas mahasiswa dalam proses pembelajaran dapat tercipta suasana belajar yang aktif.

Tabel 8 menunjukkan hasil keaktifan mahasiswa selama pembelajaran pada siklus I dan II dengan komponen penilaian meliputi kemampuan bertanya, kemampuan menjawab pertanyaan, kemampuan berdiskusi, dan kemampuan presentasi. Berdasarkan data tersebut, pada siklus I dapat dijelaskan bahwa terdapat 5 mahasiswa bertanya, 7 mahasiswa menjawab pertanyaan, 10 mahasiswa berdiskusi, dan 8 mahasiswa yang presentasi dengan baik sehingga total jumlah mahasiswa yang aktif dalam pembelajaran sebanyak 30 mahasiswa. Hal ini menunjukkan kriteria keberhasilan keaktifan mahasiswa sesuai dengan ketetapan yang dibuat oleh peneliti.

Siklus II

Hasil belajar pada siklus I belum tuntas di atas KKM, sehingga penelitian berlanjut ke siklus II. Tahap perencanaan dimulai dengan mempersiapkan topik/materi yang harus dipecahkan dalam diskusi sampai membuat soal posttest. Selama pembelajaran, dosen melakukan refleksi terhadap kekurangan-kekurangan yang terjadi selama siklus I agar tujuan pembelajaran tercapai. Hasil refleksi berdasarkan komentar dan pengamatan observer yaitu perlu ditingkatkan adanya penguasaan kelas, lebih banyak memberikan motivasi, dan harus menciptakan keterlibatan kelas sehingga semua mahasiswa di dalam kelas menunjukkan keaktifannya. Sehingga pada siklus II, hasil refleksi inilah yang dilakukan. Hal ini senada dengan apa yang diungkapkan oleh Eveline (dalam Purwanti, 2017, ) yang menyatakan bahwa pembelajaran aktif bertujuan untuk mengoptimalkan penggunaan semua potensi yang dimiliki oleh mahasiswa, sehingga dapat mencapai hasil belajar yang memuaskan.

Setelah selesai perkuliahan dosen memberikan soal posttest untuk mengetahui hasil belajar mahasiswa. Soal posttest diberikan untuk mengetahui apakah mahasiswa benar-benar memahami perkuliahan yang telah berlangsung. Hasil belajar yang diperlihatkan melalui nilai rata-rata posttest yaitu 85,34 . Terlihat adanya kenaikan nilai rata-rata yang sangat tajam dari posttest siklus I ke posttest siklus II sebesar 14,67. Perbandingan hasil pretest dan posttest pada siklus I dan II dapat dilihat pada Gambar 1 di bawah ini.

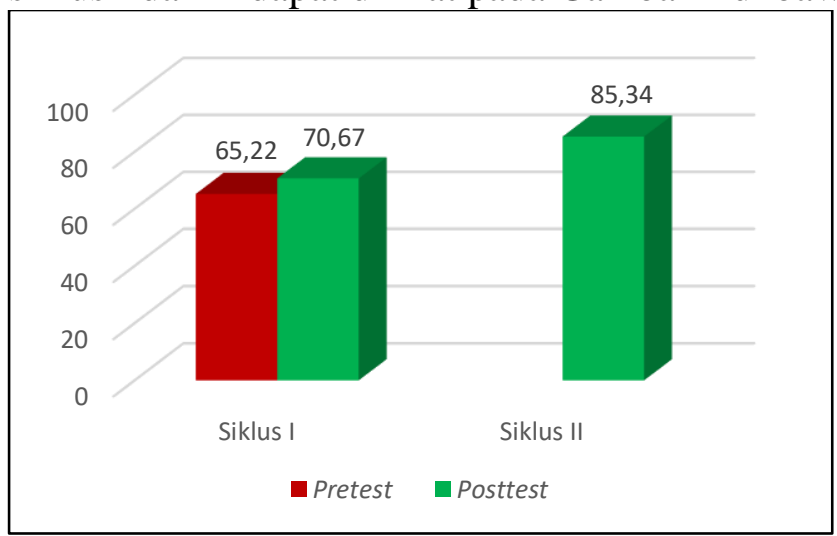

Gambar 1. Diagram Batang Hasil Pretest dan Posttest Siklus I dan II

Dari diagram batang di atas, terlihat kenaikan hasil belajar pretest dan posttest yang berarti menunjukkan penerapan metode pembelajaran small group discussion di kelas memberikan hasil yang signifikan. Hasil kenaikan nilai pretest dan posttest menunjukkan bahwa mahasiswa telah memahami materi IAD pada perkuliahan yang telah dilaksanakan.

Selama proses perkuliahan, dosen melakukan observasi keaktifan mahasiswa yang meliputi keaktifan bertanya, menjawab pertanyaan, berdiskusi, dan presentasi. Hasil keaktifan mahasiswa pada siklus I dan II dapat dilihat pada Gambar 2 di bawah ini. 


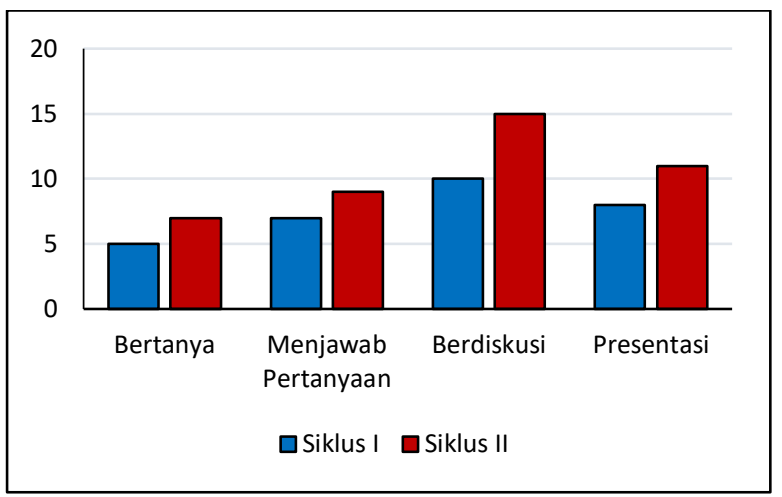

Gambar 2. Diagram Batang Keaktifan Mahasiswa Siklus I dan II

Sebelum adanya tindakan perkuliahan dengan penerapan metode pembelajaran small group discussion, hanya 15 mahasiswa yang aktif dan setelah adanya tindakan, pada siklus I mahasiswa yang aktif mencapai 30 orang, dan pada siklus II mahasiswa yang aktif meningkat menjadi 42 orang. Untuk rincian datanya dapat dilihat pada Tabel 8. Metode pembelajaran small group discussion dapat memfasilitasi mahasiswa untuk dapat aktif bertanya, berdiskusi, menghargai pendapat orang lain dan menyampaikan pendapat. Mahasiswa dapat dengan leluasa menyampaikan pendapat tanpa harus malu berbicara di depan kelas, karena mereka hanya berada dalam kelompok-kelompok kecil. Meskipun begitu, mereka sudah dikelompokkan secara heterogen. Artinya, heterogen berdasarkan variasi kemampuan, jenis kelamin, bahkan suku/ras. Mahasiswa semester I juga masih dalam masa peralihan dari Sekolah Menengah Atas (SMA) ke bangku kuliah, sehingga membuat mereka masih harus banyak menyesuaikan diri.

Adanya kenaikan keaktifan mahasiswa pada siklus I ke II menunjukkan bahwa metode small group discussion dapat digunakan untuk meningkatkan keaktifan mahasiswa Pendidikan Bahasa Inggris STKIP Paracendekia NW Sumbawa pada mata kuliah IAD. Hal ini senada dengan yang diungkapkan oleh Anton (2001) dan Ardi (2007) bahwa segala kegiatan-kegiatan yang terjadi baik fisik maupun non-fisik merupakan sebuah aktivitas yang dapat dinilai. Aktivitas belajar mahasiswa adalah kegiatan yang dapat menunjang keberhasilan belajar karena seluruh aktivitas mahasiswa dalam proses belajar baik mulai kegiatan fisik sampai kegiatan psikis merupakan aktivitas belajar. Jadi, dapat disimpulkan bahwa keaktifan mahasiswa merupakan segala kegiatan yang dilakukan dalam proses interaksi antara dosen dengan mahasiswa dalam rangka mencapai tujuan belajar dan aktivitas yang dilakukan akan ditekankan pada mahasiswa karena dengan adanya keaktifan dan aktivitas mahasiswa dalam proses pembelajaran dapat tercipta suasana belajar yang aktif.

\section{KESIMPULAN}

Metode pembelajaran small group discussion dapat meningkatkan hasil belajar dan keaktifan mahasiswa Pendidikan Bahasa Inggris STKIP Paracendekia NW Sumbawa pada mata kuliah IAD. Nilai rata-rata pretest pada siklus I yaitu 65,22 dan nilai rata-rata posttest 70,67. Nilai posttest pada siklus I masih di bawah KKM sehingga perlu dilanjutkan ke siklus II dan pada siklus II nilai rata-rata posttest berada di atas KKM yaitu 85,34 sehingga sudah mencapai kriteria keberhasilan yang ditetapkan dalam penelitian ini. Adapun keaktifan mahasiswa juga meningkat, dari sebelum adanya tindakan mahasiswa yang aktif hanya 15 orang, kemudian pada siklus I setelah adanya tindakan, mahasiswa yang aktif dalam bertanya, menjawab pertanyaan, berdiskusi, dan presentasi sebanyak 30 orang dan pada siklus II mahasiswa yang aktif mencapai 42 orang. Jadi, kriteria keberhasilan keaktifan mahasiswa sudah berhasil baik pada siklus I maupun pada siklus II dan sudah sesuai dengan tujuan penelitian ini. 


\section{SARAN}

Penelitian ini termasuk ke dalam penelitian yang subjektif sehingga mengharuskan peneliti dan observer untuk teliti dalam mengamati aktivitas mahasiswa di dalam kelas, karena hasil penelitian akan dipengaruhi oleh pengamatnya. Jadi, penting untuk mempersiapkan observer yang jeli dan teliti untuk mengamati aktivitas mahasiswa. Dosen maupun tenaga pendidik yang berkecimpung dalam dunia pendidikan dapat melakukan perkuliahan maupun pengajaran dengan menerapkan metode pembelajaran small group discussion manakala dosen maupun guru ingin meningkatkan hasil belajar dan keaktifan siswa/mahasiswa di kelas, karena metode pembelajaran ini telah terbukti dapat meningkatkan hasil belajar dan keaktifan mahasiswa sekaligus untuk menambah kontribusi serta khasanah ilmu dalam dunia pendidikan.

\section{UCAPAN TERIMA KASIH}

Terimakasih penulis ucapkan kepada ketua STKIP Paracendekia NW Sumbawa dan ketua LPPM yang telah mendanai penelitian ini hingga tersusunnya tulisan ini. Tak lupa pula, penulis memberikan ucapan terimakasih kepada rekan-rekan mahasiswa yang telah banyak membantu penelitian ini mulai dari persiapan semua fasilitas yang digunakan dalam kegiatan pembelajaran di kelas sampai menjadi observer ketika penelitian berjalan.

\section{DAFTAR PUSTAKA}

Aly, A., \& Rahma, E. (2015). Ilmu Alamiah Dasar. Jakarta: Bumi Aksara.

Ardi, R. E. (2007). Peningkatan Aktivitas dan Hasil Belajar Matematika dengan Penerapan Model Pembelajaran Kooperatif STAD 2006/2007. Universitas Negeri Semarang.

Arikunto, S. (2009). Dasar-Dasar Evaluasi Pendidikan. Jakarta: Bumi Aksara.

Djamarah, B., Syaiful, Z., Aswan. (2013). Strategi Belajar Mengajar. Jakarta: Rineka Cipta.

Fahmi, S. (2011). Pembelajaran Kooperatif: Artikel Pendidikan Matematika. Jogjakarta: UAD

Hamalik, O. (2006). Teknologi dalam Pendidikan. Bandung: Yayasan Partisipasi Pembangunan Indonesia.

Nafsri, L. (2014). Penerapan Strategi Small Group Discussion untuk Meningkatkan Hasil Belajar IPA Siswa Kelas IVB SDN 02 Tanah Grogot. J-TEQIP, 5(1), 56-61.

Purwanti, S. (2017). Penerapan Small Group Discussion untuk Meningkatkan Hasil Belajar dan Keaktifan Mahasiswa PGSD UAD. Jogjakarta: Jurnal Dialektika Jurusan PGSD. 5(1), 10-19.

Putriawati, W. (2014). Prosiding Semnas Sains: Penerapan Metode Quantum Learning Berbasis Mind Mapping terhadap Prestasi Belajar Siswa Kelas X Materi Pokok Hidrokarbon. Surabaya: UNESA, (015-1023).

Putriawati, W. (2016). Tesis: "Pemetaan Tingkat Konflik Kognitif Siswa SMA pada Konsep Asam-Basa". Surabaya: UNESA

Rusmanto. (2013). Model-model Pembelajaran. rusmant0.blogspot.co.id/2013/12/smallgroup-discussion.html. Diakses pada tanggal 10 Desember 2017.

Sanjaya. (2010). Penelitian Tindakan Kelas. Jakarta: Kencana Predana Media Group. 